\title{
Damages of spittlebug on sugarcane quality and fermentation process
}

\author{
Débora Branquinho Garcia ${ }^{1}$; Gisele Cristina Ravaneli후 Leonardo Lucas Madaleno²; Miguel \\ Angelo Mutton ; Márcia Justino Rossini Mutton ${ }^{4 *}$ \\ ${ }^{1}$ UNESP/FCAV - Programa de Pós-Graduação em Microbiologia Agropecuária. \\ ${ }_{3}^{2} U N E S P / F C A V$ - Programa de Pós-Graduação em Produção Vegetal. \\ ${ }^{3} U N E S P / F C A V$ - Depto. de Produção Vegetal, Jaboticabal, SP - Brasil. \\ ${ }^{4} U N E S P / F C A V$ - Depto. de Tecnologia, Via de Acesso Prof. Paulo Donato Castellane s/n. - 14884-900 - \\ Jaboticabal, SP - Brasil. \\ "Corresponding author <mjrmut@fcav.unesp.br>
}

\begin{abstract}
The quality of the raw material defines the industrial potential production. The harvest of raw sugarcane promoted a favorable environment for the increase of Mabanarva fimbriolata (Stål, 1854) pest that affects the plant development. This research was undertaken to evaluate the effects of $M$. fimbriolata on sugarcane quality and fermentation process. For the technological analysis, four damage levels and two evaluation periods were evaluated, while four fermentation cycles and two evaluation periods were tested for microbiological analysis, with three replications. The determined parameters were Brix (soluble solids), Pol (apparent sucrose), Purity, reducing sugars (RS), total reducing sugars (TRS), Total Acidity, pH and Total Phenolic Compounds in juice. In the fermentation process cellular viability analysis, yeast sprout and bacterial concentration were carried out. The wine was submitted to alcohol content, TRRS (total residual reducing sugars) and fermentation efficiency. The treatment with 60\% of damage steams exhibited the lowest averages of Brix, Pol, Purity and TRS of the juice. An increase of the RS\% of the juice and content of total phenolic compounds was observed. The cellular and sprouts viability were reduced with the increase in the damages caused by $M$. fimbriolata. The fermentation process exhibited larger quantities of contaminators. With the damages, the wine TRRS quantity was superior and, consequently there was a decrease of the alcoholic content and fermentation efficiency. The damages caused by $M$. fimbriolata affected the quality of the raw material, compromising the fermentative process, and increase the production of phenolic compounds and contaminators. Key words: Mahanarva fimbriolata infestation, Saccharum spp., ethanolic fermentation
\end{abstract}

\section{Danos promovidos por cigarrinha-das-raízes na qualidade da cana e processo fermentativo}

\begin{abstract}
RESUMO: A qualidade da matéria-prima define o potencial de produção da indústria. A colheita de cana sem queima proporcionou um ambiente favorável ao aumento da infestação da Mahanarva fimbriolata (Stål, 1854), que suga a planta e afeta seu desenvolvimento. Avaliaram-se os danos promovidos pela $M$. fimbriolata na qualidade da cana e no processo fermentativo. Os tratamentos utilizados foram quatro níveis de danos e duas épocas de avaliações para as análises tecnológicas, e quatro níveis de danos, quatro ciclos fermentativos e duas épocas de avaliações para as análises microbiológicas com três repetições. Foram determinados Brix (sólidos solúveis), Pol (sacarose aparente), Pureza, açúcar redutor total (ART), açúcar redutor (AR), Acidez Total, pH, e teor de compostos fenólicos totais no caldo. No processo fermentativo foram realizadas análises de viabilidade celular, brotos de leveduras e concentração de bactérias. Determinaram-se açúcar redutor residual Total (ARRT), teor alcoólico nos vinhos e a eficiência da fermentação. Os tratamentos com $60 \%$ dos colmos danificados apresentaram menor média de Brix, Pol, Pureza e ART do caldo. Verificou-se aumento do AR\% caldo e dos teores de compostos fenólicos totais. A viabilidade celular e de brotos foram reduzidas com o aumento dos danos provocados pela $M$. fimbriolata. O processo fermentativo apresentou maiores quantidades de contaminantes. Com os danos a quantidade de ARRT dos vinhos foi maior, houve redução do teor alcoólico, assim como na eficiência da fermentação. Os danos causados pela $M$. fimbriolata afetaram a qualidade da matéria-prima, comprometendo o processo fermentativo, além de aumentar a produção de compostos fenólicos e contaminantes.

Palavras-chave: Mahanarva fimbriolata, Saccharum spp., fermentação etanólica
\end{abstract}

\section{Introduction}

The production of sugarcane (Saccharum spp.) is a matter of worldwide importance because through indus- trial processing, sugarcane is a highly efficient source of sugar and the biofuel ethanol. All occurrences that could limit the development of sugarcane can, as a result, diminish its quality as raw material, and therefore 
may affect the industrial process which results in these important bioproducts (Ravaneli et al., 2006). The incidence of pest in these crops, such as that caused by the insect Mahanarva fimbriolata (Stål, 1854) (Hemiptera: Cercopidae) is one of the most important causes of diminished sugarcane growth.

The emergence of $M$. fimbriolata as an occurring pest in sugarcane resulted from environmental conditions that were found to be adequate for the insect's development. Among these conditions, the presence of straw on raw sugarcane is one of the most important. When sugarcane is infested by nymph and adult stages of $M$. fimbriolata, it suffers damage to its stalks, which become thinner and drier than those from non-infested areas (Dinardo-Miranda et al., 2000). Sugarcane infested by this pest constitutes raw material for industrial processing with reduced levels of sucrose (Mendonça et al., 1996) and of soluble solids (Brix) (Gonçalves et al., 2003). The pest causes a state of hydric stress, with the stalks frequently presenting cracks that may originate deterioration, which, in turn, can make the plant susceptible to contaminants. When these contaminants occur in high levels, they inhibit the process of fermentation and impair the extraction of sugar, thus diminishing the results obtained by industrial processing (Dinardo-Miranda, 2003).

When attacked by pest, plants can produce substances such as phenolic compounds which act as a defence since these can interfere negatively in the metabolism of yeasts (Polakovic et al., 1992). Since yeasts play an active part in the fermentation process, when the raw material is of reduced quality the viability of yeast cells in this process is diminished (Gonçalves et al., 2003 and Ravaneli et al., 2006).

With the purpose of contributing with more information regarding this problem, the present study was carried out to assess losses in sugarcane quality, microrganism content of the juice and in the fermentation process caused by the spittlebug.

\section{Material and Methods}

\section{Assay set up and conduction}

The present assay was conducted in Guariba, state of São Paulo, Brazil. The sugarcane variety used in the assay was the SP80-1842 from a 5th cut, which would be susceptible to pest infestations, and whose last cut had been done through mechanical harvest with no trash burn. Plant evaluation was carried out at two seasons of the year, with one assessment performed at the end of the rainy season in May/June (winter), and the other in October (springtime), after the dry season of 2007.

The method proposed by Gonçalves et al. (2003) was used to set up the two treatments used in the assay. This method establishes a classification of stalks based on the degree of damage sustained after a pest infestation. In the present study all stalks that did not show damage to its external layer and presented a live apical meristem were classified as "apparently healthy"; those which presented apparent external damage and a dry apical mer- istem but which lower meristem was still green were classified as "damaged", whereas those which were still attached to the stalk clump, although completely dry, were classified as "dry" stalks.

Each treatment was composed of a bundle of 20 stalks which represented one of the following levels of damage: $0 \%$ damage (20 apparently healthy stalks), 15\%damage (17 apparently healthy stalks +2 damaged stalks + 1 dry stalk), 30\% damage (14 apparently healthy stalks +4 damaged stalks +2 dry stalks) and $60 \%$ damage $(8$ apparently healthy stalks +8 damaged stalks +4 dry stalks).

Technical analysis of the sugarcane juice produced was carried out using random sampling with a factorial $4 \times 2$ design, with the primary treatments being considered the levels of damage promoted by pest infestation $(0,15,30$ and $60 \%)$, and the secondary treatments the two different periods of assessment (May/ June and October), with three replications. Regarding the fermentation process, an additional factor was considered, completing a $4 \times 4 \times 2$ design, with the primary treatments being the damaged caused by the spittlebug $(0,15,30$ and $60 \%)$, the secondary treatments four fermentation cycles $\left(1^{\text {st }}, 4^{\text {th }}, 7^{\text {th }}\right.$ and $\left.10^{\text {th }}\right)$ and the third treatments the two periods of assessment (two seasons), with three replications.

Stalks harvested at each determined season were cleared of straw and cut off at the height of the apical bud. Afterwards, the treatments were composed, identified and the stalks were transported to the site of juice extraction, which was done according to method described by Tanimoto (1964). Brix (soluble solids) and Pol (apparent sucrose) values were determined as described by Schneider (1979) and Apparent Purity of the juice according to Consecana (2008). The $\mathrm{pH}$ values were determined by direct reading using a digital $\mathrm{pH}$ meter, with temperature corrected at $25^{\circ} \mathrm{C}$. The reducting sugars (RS) were calculated according to Consecana (2008) and the total reducting sugars (TRS) according to the volumetric method by Lane and Eynon (1934). Total acidity was determined by titration of the juice when being mixed with a standard $\mathrm{NaOH} 0.05 \mathrm{~N}$ solution (Copersucar, 2001). Total phenolic compounds were determined according to Folin and Ciocalteau (1927).

\section{Characterization of the fermentation process}

To obtain the must, the extracted juice was clarified by the addition of $300 \mathrm{mg} \mathrm{L}^{-1}$ phosphoric acid $\left(\mathrm{H}_{3} \mathrm{PO}_{4}\right)$, with posterior adjustment of $\mathrm{pH}$ to 7.0 by adding $\mathrm{Ca}(\mathrm{OH})_{2}\left(6^{\circ} \mathrm{Bé}\right)$. The treated juice was heated until attaining temperatures of 100 to $105^{\circ} \mathrm{C}$ and then $2 \mathrm{mg}$ $\mathrm{L}^{-1}$ of the polymer (Mafloc 985) was added. The juice was then transferred to a $1 \mathrm{~L}$ beaker for decantation of impurities (mud or lees). The decanted lees was separated by filtration and then discarded. The clarified juice was brought to standard at $13^{\circ}$ Brix at the first period and $14^{\circ}$ Brix at the second period of assessment. Afterwards, pH was brought to standard at $3.5( \pm 0.3)$ 
using sulfuric acid and then the juice was heated to $32^{\circ} \mathrm{C}$, thus obtaining the must for the fermentation process.

The inoculum used for the fermentation process was composed of pressed yeast (Fleischmann) at $30 \mathrm{~g} \mathrm{~L}^{-1}$. Must was added twice to the juice, with a 30 min interval, getting a final volume of $500 \mathrm{~mL}$ in each beaker. These were stored in germination incubators, with internal temperatures stabilized at $32^{\circ} \mathrm{C}$, and the fermentation process was monitored (every $4 \mathrm{~h}$ ) by a ${ }^{\circ} \mathrm{Brix}$ densimeter. The end of the process was determined when the Brix values attained 1 or less, or when the readings at $30 \mathrm{~min}$ intervals were stable.

At the end of each fermentation cycle, the yeast was recovered by centrifugation at $1650 \mathrm{x} \mathrm{g}$ for 5 minutes at $25^{\circ} \mathrm{C}$. The recovered yeast was then washed with a sterile $0.85 \%$ saline solution and submitted to agitation for $1 \mathrm{~h}$ at $32^{\circ} \mathrm{C}$, with $0.5 \%$ glucose and was acidified with $\mathrm{H}_{2} \mathrm{SO}_{4}$ to reduce $\mathrm{pH}$ when this was found to be higher than 3.5. This process produced the inoculum that was then used in the next cycle of fermentation.

Samples of the wine were taken at the beginning and again at the end of the fermentation process for microbiologic evaluation. A hemocytometer was used for assessing cells and sprout viability and the concentration of bacteria present (Ravaneli et al., 2006). A digital densitometer was used to assess alcoholic levels in the wine (Amorim, et al. 1979), and the total residual reducting sugars (TRRS) were determinate as according to Lane and Eynon (1934).

Results obtained were submitted by analysis of variance by the $\mathrm{F}$ Test and the mean values were compared according to Tukey's test $(p=0.05)$ (Banzatto and Kronka, 2006).

\section{Results and Discussion}

When the raw material used presented damage, a reduction of the technological quality of sugarcane juice was observed (Table 1). A significant effect was observed regarding the levels of damage and the moment (season) of harvest. Brix, Pol and Purity of juice values were found to be lower, with the lowest average result when using the raw material from the treatment that presented $60 \%$ of the stalks damaged. For the TRS, the treatment with $60 \%$ of damage already presented a mean value that was smaller than those from the other treatments (Table 1). Gonçalves et al. (2003) also found lower Brix and Pol values in raw sugarcane material attacked by this pest when the damage was extensive. These results could be due to plant stress, which would give it a scorched appearance because of the dry stalks (Mendonça, 1996). Furthermore, when assessing the originated juice's RS\% values, these were found to be increased when the raw material presented damage (Table 1).

When a plant suffers injury, due to pest for example, it alters its metabolism and initiates the production of more compounds which are used as a mechanism of defence against the attack. This production requires the use of extra amounts of energy which are attained from glucose breakdown. In the present experiment, sugarcane attacked by the pest produced more glucose and amassed a smaller sucrose content, thus presenting lower Brix, Pol, Purity and TRS values (Table 1).

At the time of the second assessment the sugarcane had matured. Normally, after this process, sugarcane will present a higher content of sugar in the form of sucrose and, thereafter, juice will present higher Brix, Pol, Purity and TRS values and smaller RS values. The re-

Table 1 - Analysis of variance for Brix, Pol, Purity, TRS, RS, pH, total acidity and total phenolic compounds.

\begin{tabular}{|c|c|c|c|c|c|c|c|c|}
\hline Variation causes & Brix Juice & Pol Juice & Purity Juice & RS Juice & TRS Juice & pH Juice & Total Acidity & Phenol Juice \\
\hline & \multicolumn{6}{|c|}{ 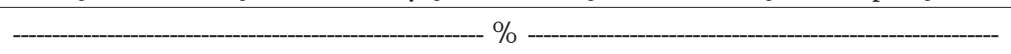 } & $\mathrm{gH}_{2} \mathrm{SO}_{4} \mathrm{~L}^{-1}$ & $\mu \mathrm{g} \mathrm{mL}^{-1}$ \\
\hline \multicolumn{9}{|c|}{ Damage levels (A) } \\
\hline $0 \%$ & 20.16 a & $17.33 \mathrm{a}$ & 85.41 a & $0.71 \mathrm{~b}$ & 18.66 a & $5.27 \mathrm{a}$ & $1.09 \mathrm{~b}$ & $392.03 \mathrm{~b}$ \\
\hline $15 \%$ & $20.04 \mathrm{a}$ & $17.15 \mathrm{a}$ & $85.16 \mathrm{a}$ & $0.72 \mathrm{~b}$ & $18.38 \mathrm{ab}$ & $5.26 \mathrm{ab}$ & $1.13 \mathrm{ab}$ & $412.31 \mathrm{ab}$ \\
\hline $30 \%$ & $19.86 \mathrm{a}$ & $16.78 \mathrm{a}$ & $84.11 \mathrm{ab}$ & $0.76 \mathrm{~b}$ & $17.96 \mathrm{~b}$ & $5.20 \mathrm{~b}$ & $1.19 \mathrm{ab}$ & $434.14 \mathrm{ab}$ \\
\hline $60 \%$ & $19.06 \mathrm{a}$ & $15.89 \mathrm{~b}$ & $82.66 \mathrm{~b}$ & $0.81 \mathrm{a}$ & $17.39 \mathrm{c}$ & $5.09 \mathrm{c}$ & $1.25 \mathrm{a}$ & $457.05 \mathrm{a}$ \\
\hline $\mathrm{F}$ & $5.46 \% *$ & $11.50 \% *$ & $5.06 \%$ & $5.10 \% *$ & $13.97 \% *$ & $18.84 \% *$ & $4.45 \%$ & $3.71 \%$ \\
\hline DMS (Tukey) & 0.78 & 0.7 & 2.05 & 0.07 & 0.55 & 0.07 & 0.12 & 53.73 \\
\hline \multicolumn{9}{|l|}{ Periods (B) } \\
\hline May/June & $15.23 \mathrm{~b}$ & $11.96 \mathrm{~b}$ & $79.41 \mathrm{~b}$ & $0.92 \mathrm{a}$ & $12.97 \mathrm{~b}$ & $5.26 \mathrm{a}$ & $1.23 \mathrm{a}$ & $323.33 \mathrm{~b}$ \\
\hline October & $24.33 \mathrm{a}$ & $21.61 \mathrm{a}$ & 89.26 a & $0.58 \mathrm{~b}$ & $23.22 \mathrm{a}$ & $5.15 \mathrm{~b}$ & $1.11 \mathrm{~b}$ & $524.44 \mathrm{a}$ \\
\hline $\mathrm{F}$ & $1841.1 \%$ & $2596.6 \% *$ & $315.1 * *$ & $317.8 \%$ & $4743.7 \%$ & $30.1 \%$ & $13.8 \% *$ & $191.1 * *$ \\
\hline DMS (Tukey) & 0.42 & 0.37 & 1.09 & 0.04 & 0.29 & 0.04 & 0.06 & 28.82 \\
\hline$A \times B$ & $0.18^{\mathrm{ns}}$ & $0.19^{\mathrm{ns}}$ & $1.01^{\mathrm{ns}}$ & $1.02^{\mathrm{ns}}$ & $1.99^{\mathrm{ns}}$ & $8.28^{\mathrm{ns}}$ & $2.56^{\mathrm{ns}}$ & $0.73^{\mathrm{ns}}$ \\
\hline CV (\%) & 5.87 & 6.18 & 3.6 & 13.89 & 4.5 & 2.02 & 15.11 & 18.8 \\
\hline
\end{tabular}

Identical letters do not differ (Tukey, $p<0.05$ ) by the column. ns = non significant; *significant at $5 \%$; **significant at $1 \%$; TRS = Total reducting sugars; $\mathrm{RS}=$ Reducing sugars. 
sults obtained in the present study were found to be in accordance to this expectation (Table 1).

The assessment of $\mathrm{pH}$ values of found in the sugarcane when harvested and of the significant relation between these values and the level of damage sustained by the plant showed that the longer the damaged stalks remained in the field, more intense was the reduction of $\mathrm{pH}$ (Table 1). Dinardo-Miranda et al. (2008) found that a delayed harvest of sugarcane infested by $M$. fimbriolata would originate a reduction in production $\left(\mathrm{t} \mathrm{ha}{ }^{-1}\right.$ cane) with a consequent reduction of apparent sucrose (pol ha $\mathrm{h}^{-1}$ ) in the raw material delivered to the industry. $\mathrm{pH}$ values in sugarcane from the treatments with the highest percentages of damage were close to 5.0 , indicating deterioration, since deteriorated sugarcane normally presents $\mathrm{pH}$ values lower than 5.0 (Stupiello, 1999).

When damage caused by the pest was greater, total acidity of the juice was also higher (Table 1), probably because of the production of acid compounds by the plant. When no pest control is done, a greater amount of contaminants are found in the plant, which causes loss of sugars which are used by these in the production of such compounds (Taiz and Zeiger, 2004). Ravaneli et al. (2006) observed an increase in acidity directly related to the increase in levels of sugarcane infestation by $M$. fimbriolata.

In the present experiment, higher concentrations of phenolic compounds were observed in the sugarcane with higher levels of damage (Table 1). Silva et al. (2005) verified that an expressive infestation of $M$. fimbriolata in sugarcane caused a rise in the phenol content of the juice produced from these plants, with the presence of these compounds being related to plant stress. To protect itself from the attack, the plant synthesizes defense biomolecules by modifying its secondary metabolism, which results in the production of compounds responsible for protection (Taiz and Zeiger, 2004).

During the long process of maturation, the plant accumulates these compounds, which concentrations culminate at the period in which the plant is harvested (Simioni et al., 2006). These findings corroborate the results found in the present experiment, in which the concentration of total phenolic compounds was found to be higher in the second period of evaluation. Presotti et al. (2007) observed the same tendency regarding this increase in concentrations of phenolic compounds in studies of plants infested by this pest.

Both initial and final viability of cells were reduced with the increase of damage caused by $M$. fimbriolata (Figure 1A). Viability of cells and sprouts at the end of the fermentation process is generally diminished when compared to that presented at the beginning, since in the initial phases of fermentation there are more nutrients and substrate available (Ravaneli et al., 2006). During the process, an exhaustion of the sugars found in the environment occurs naturally, as well as a reduction in all available nutrients and an accumulation of metabolites produced by the microorganisms that fuel the process. Another common effect is caused by the elevated concentration of ethanol resultant of the process, which causes a negative effect on the yeasts. Ravaneli et al. (2006) observed a decrease in these viabilities when nymph infestation of sugarcane increased and found that damage caused by this pest affected the quality of the must used for fermentation.

During the fermentation process, the presence of phenolic compounds can inhibit yeast reproduction, which results in diminished viability of cells and sprouts, making a difficult reutilization of cells (Ravaneli et al., 2006). In the present experiment an increase of these
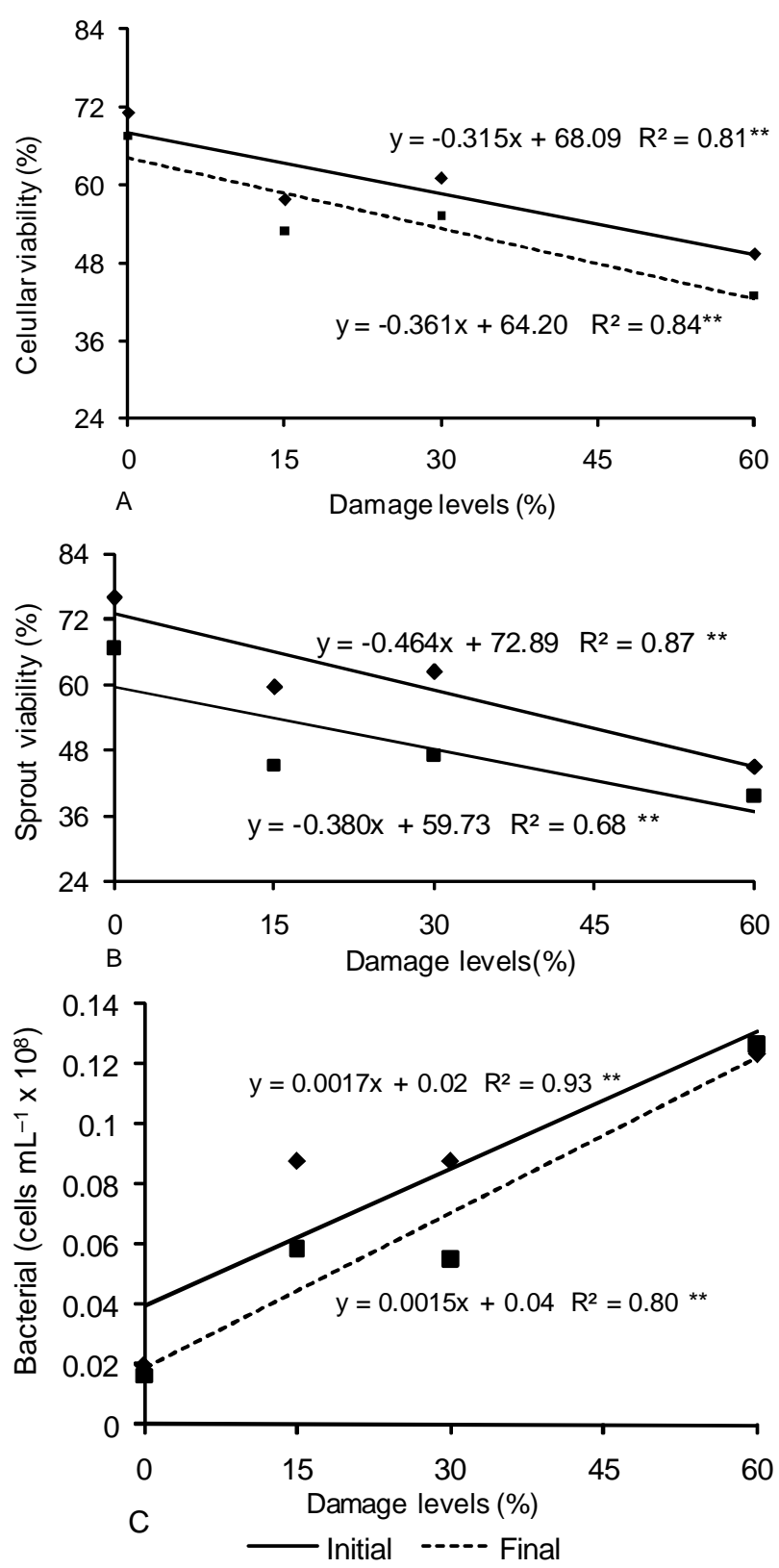

Figure 1 - Microbiologic analysis of the damage levels caused by M. fimbriolata on sugarcane. (A) - Cellular viability. (B) - Cellular viability of the sprouts. (C) - Bacterial concentrations. 
compounds in tandem with the increase in the level of damage to the plant was observed (Table 1).

The concentration of bacteria found in fermentation in the present study increased proportionally to the increase of damage of the stalks, results which were seen in the beginning as well as at the end of the process (Figure 1C). The degradation of sucrose and the formation of acid compounds that cause diminishment of sugar content and intoxication of yeasts would be the cause to the greatest loss in sugarcane production due to bacterial contamination (Oliva-Neto and Yokoya, 1997). In this study an increase in total acidity in the raw sugarcane material was observed when this had suffered an infestation by this pest (Table 1).

A reduction of viability regarding cells and sprouts was observed in the beginning and at the end of the fermentation process when assessing reutilization of yeasts in the different cycles (Figures 2A and 2B). This would probably be caused by an accumulation of stress in the yeasts, which in turn would be caused by the presence of bio-molecules that inhibit the fermentation process (Amorim et al., 1996) such as contaminants and phenolic and acid compounds, all of which were found in higher concentrations when the plant presented damage due to pest. Metabolites in the raw sugarcane and toxic compounds produced during the fermentation process, the presence of which are undesirable, can accumulate in yeasts, causing reduction in viability and reducing industrial efficiency (Okolo et al., 1987).

The concentration of bacteria increased during fermentation cycles, at the beginning as well as at the end of the process (Figure 2C). This increase in bacteria population and the presence of metabolites produced by these compromised the yeasts, because the environment in which these are found at the ending of the fermentation process is very harsh from a physical, chemical and biological point of view, weakening the yeasts and even causing the death of thousands of cells before the beginning of the next cycle (Novaes, 1992).

The amount of total residual reducing sugars (TRRS) in the wine increased with the increase in damage suffered by the plant (Figure 3A). This indicates that the yeasts were not capable of using all the sugars available to them in their environment, since compounds that impaired their metabolism were present in the damaged raw sugarcane.

A reduction of alcoholic content (Figure 3B) and a decrease in the efficiency of the fermentation process (Figure 3C) was observed when the damage to the sugarcane increased. Ravaneli et al. (2006) observed a decrease in the alcoholic levels of wine when spittlebug infestation was greater then 2.5 nymphs $\mathrm{m}^{-1}$. Furthermore, Gonçalves et al. (2003) found that the less damage suffered by the sugarcane plants, the better is the efficiency of the fermentation process.

When observing the cycles of fermentation, an increase of TRRS could be observed (Figure 4A). This could be caused by the difficulty of yeasts in promoting the process after a few cycles due to stress caused by the environment. This stress accumulated during the successive cycles of fermentation could also be responsible for the reduction found in alcoholic content (Figure $4 \mathrm{~B}$ ) of the raw material and in the efficiency of fermentation (Figure 4C) of this substrate.

When collected at the second period (season) of assessment, sugarcane presented higher sugar content (TRS) due to accumulation of sucrose that occurs in the maturation process (Table 1). Because of this, the alcoholic content of the wine process of the raw material from this period were increased but the values of efficiency of the fermentation were lower (Figures 5B and
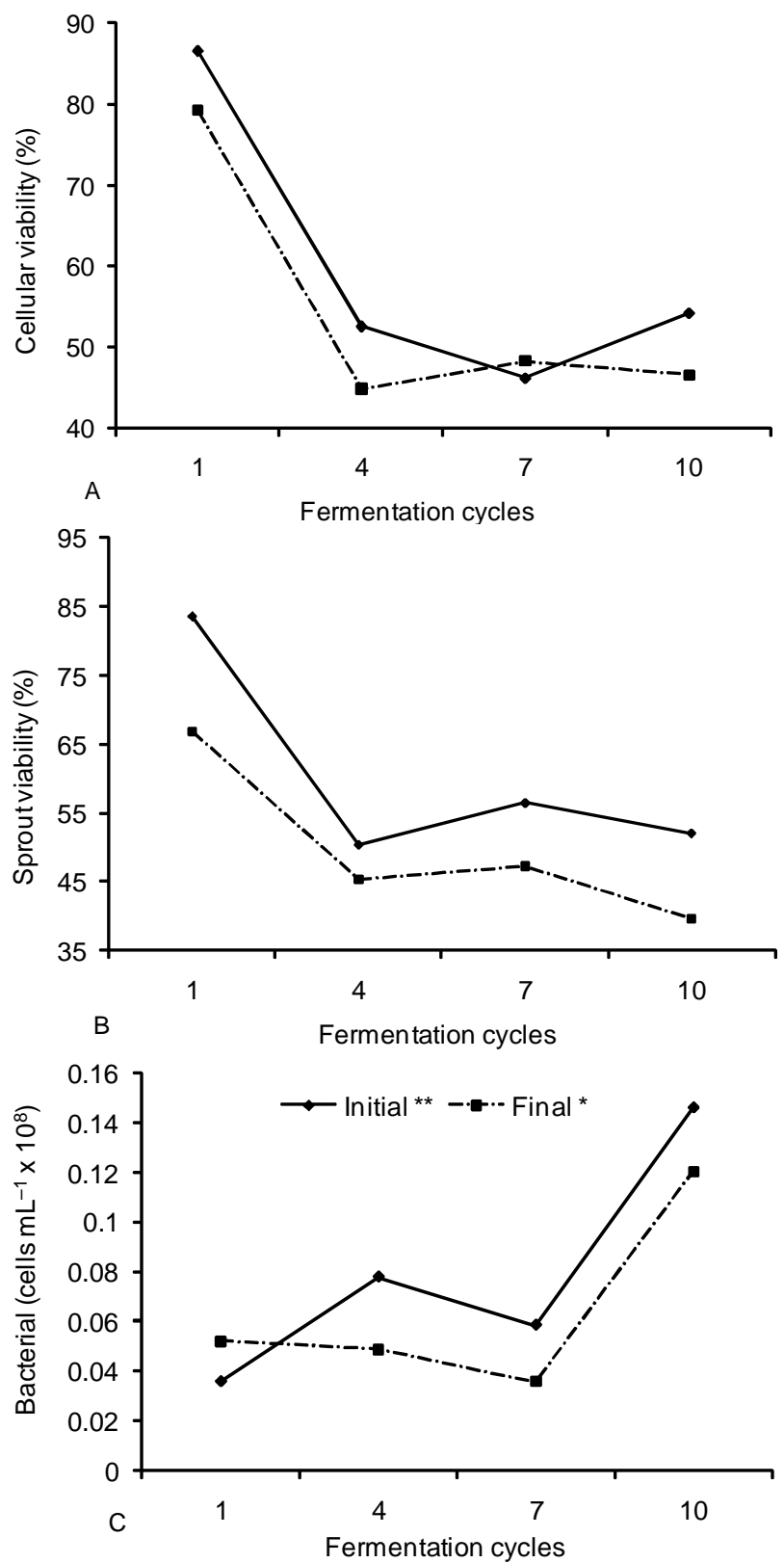

Figure 2 - Microbiologic analysis of the evaluated fermentation cycles. (A) - Cellular viability. (B) - Cellular viability of the sprouts. $(\mathrm{C})$ - Bacterial concentrations. 
Garcia et al.
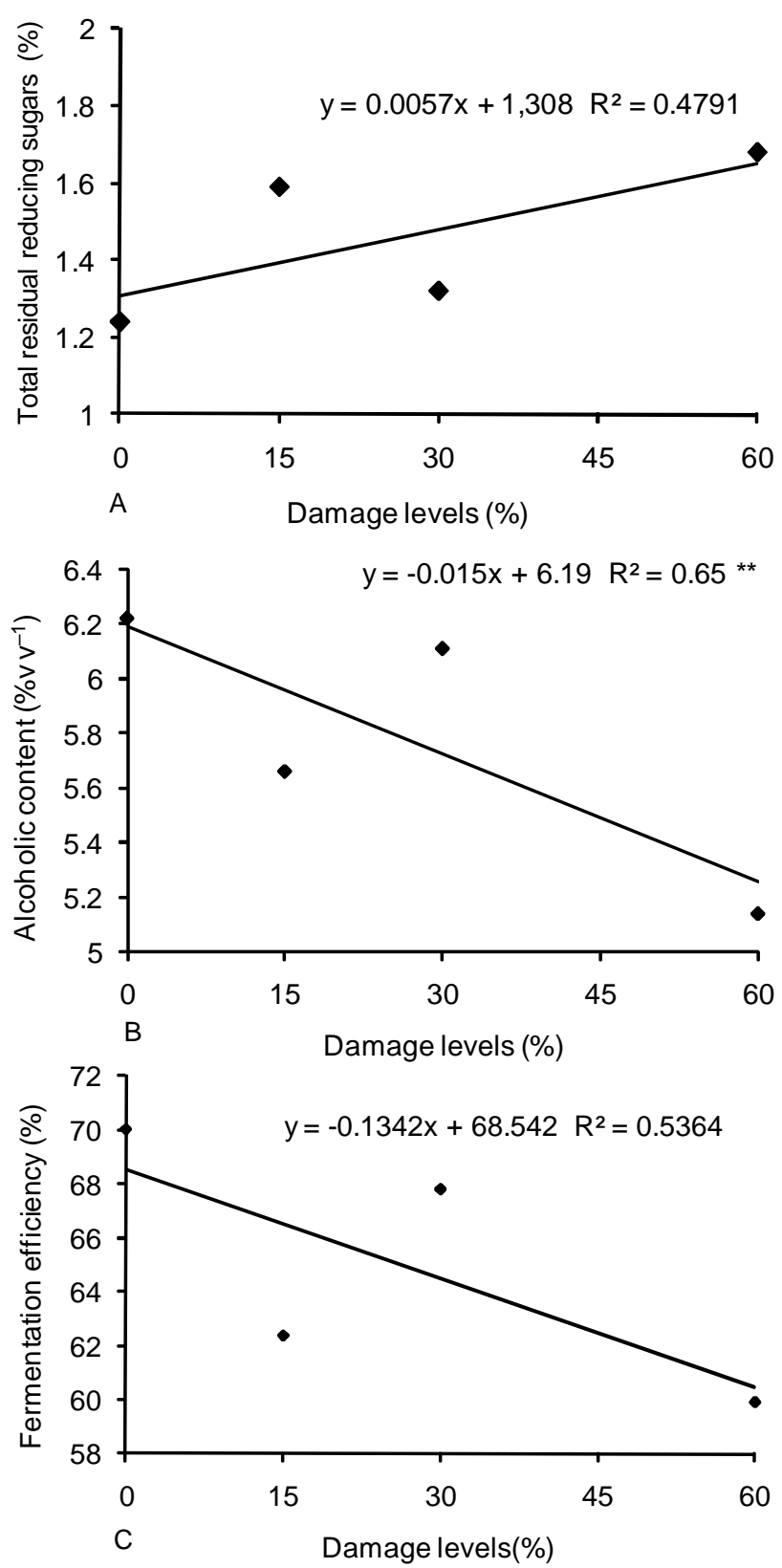

Figure 3 - Wine analysis of the damage levels caused by $M$. fimbriolata on sugarcane. (A) - Total residual reducing sugars. (B) - Alcoholic content. (C) Fermentation efficiency.

5C). When assessing the TRRS, this was also found to be increased in the second assessment period/season (Figure 5A). Levels of phenolic compounds (Table 1) and the bacteria population (Figure $2 \mathrm{C}$ ) were also increased compared to initial values, and these probably exerted a negative affect on the yeasts, impairing their capability of using the sugars available in the environment causing a lower efficiency of the fermentation.

\section{Conclusions}

Damage caused by $M$. fimbriolata has a negative affect on sugarcane quality. Raw material composed of raw
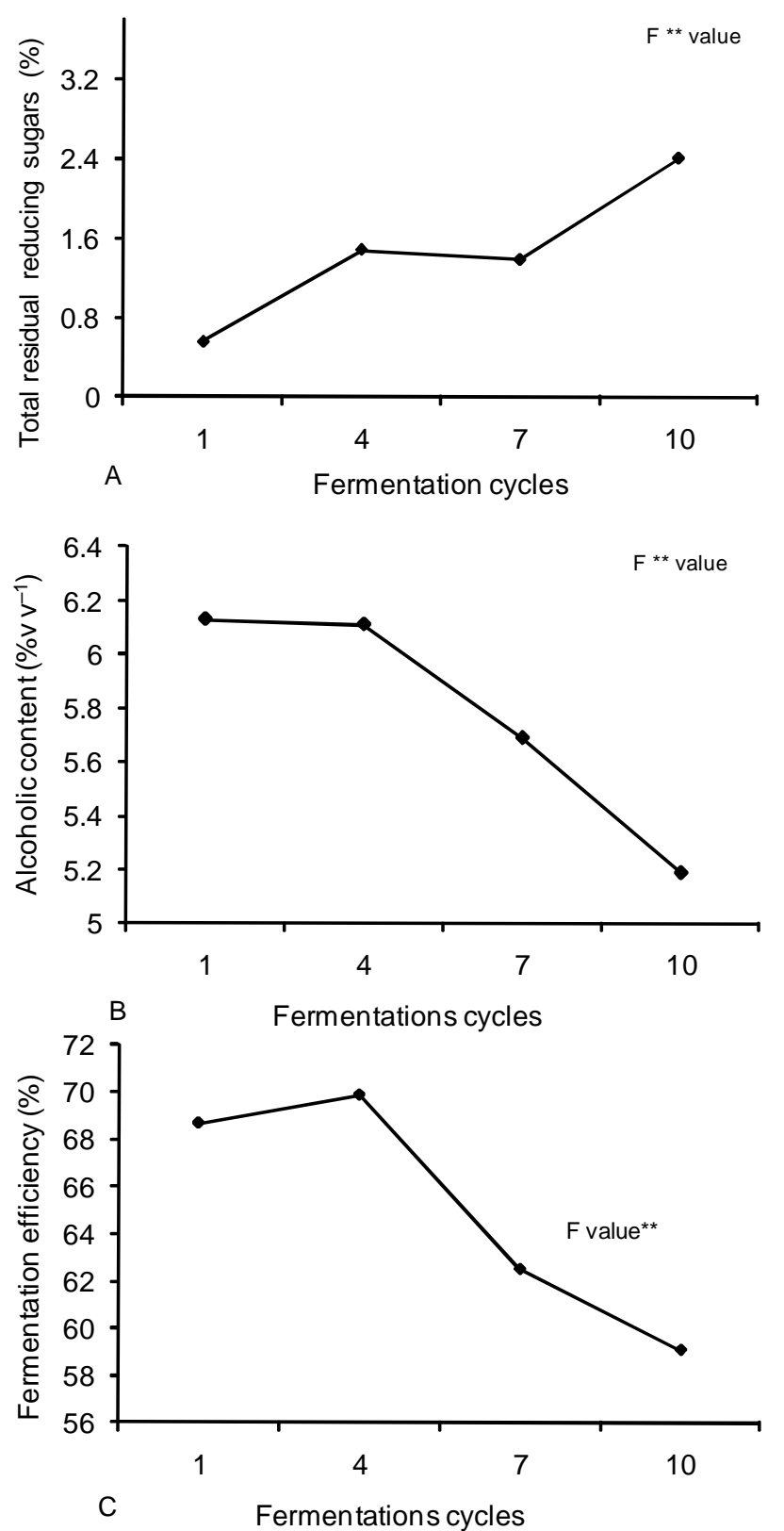

Figure 4 - Wine analysis of the evaluated fermentation cycles. (A) - Total residual reducing sugars. (B) - Alcoholic content. (C) - Fermentation efficiency.

sugarcane that sustained damage presents higher levels of contaminants and higher levels of phenolic compounds which interfere and impair the fermentation process. Sugarcane afflicted with pest presents reduced yeast viability, wine with a reduced alcoholic content and reduced efficiency of the fermentation process.

\section{Acknowledgement}

To the company Louis Dreyfus Commodities Bioenergia S/A: São Carlos Sugarcane mill for the experimental area, to FAPESP for the financial support, to CAPES for the scholarship. 

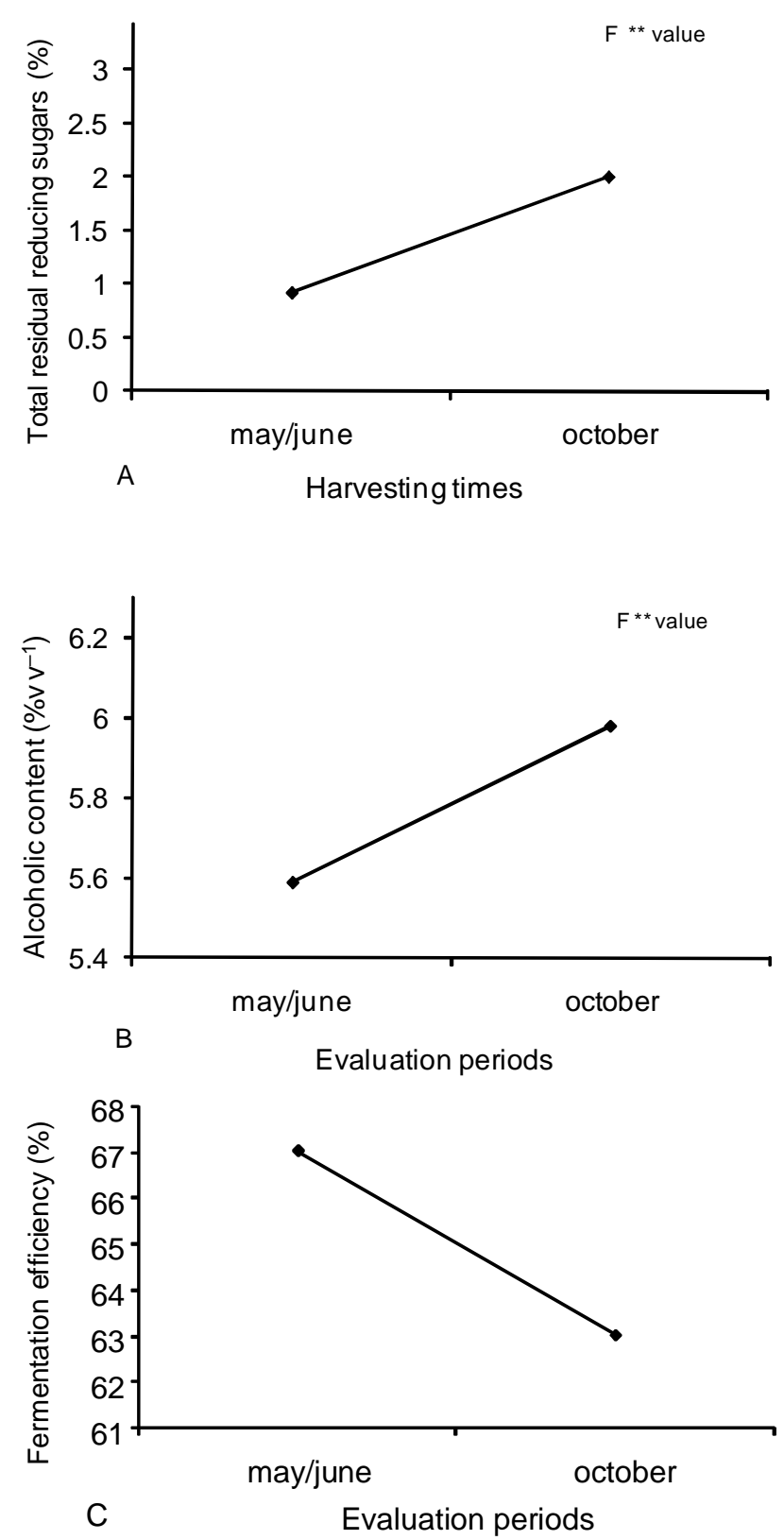

Figure 5 - Wine analysis of the evaluation periods. (A) - Total residual reducing sugars. (B) - Alcoholic content. (C) - Fermentation efficiency.

\section{References}

Amorim, H.V.; Zago, E.A.; Gutierrez, L.E. 1979. Rapid method for control the fermentation and destilation. Saccharum 2: 3134. (in Portuguese).

Amorim, H.V.; Basso, L.C.; Alves, D.G. 1996. Processes of Alcohol Production- Control and Monitoring. Fermentec/Fealq/ ESALQ-USP, Piracicaba, SP, Brazil. (in Portuguese).

Banzatto, D.A.; Kronka, S.N. 2006. Agricultural Experimentation. 4ed. FUNEP, Jaboticabal, SP, Brazil. (in Portuguese).

Consecana. 2008. Standards for Quality Assessment of Cane Sugar. Available at: http://www.unica.com.br/files/consecana/ normasepreços.pdf [Accessed Apr. 14, 2008]. (in Portuguese).

Copersucar. 2001. Chemical control of sugar manufacture handbook. Piracicaba, SP, Brazil. (in Portuguese).
Dinardo-Miranda, L.L.; Ferreira, J.M.G.; Carvalho, P.A.M. 2000. Influence of spittlebugs, Mabanarva fimbriolata, on the technological quality of sugarcane. STAB Açúcar, Álcool e Subprodutos 19: 34-35. (in Portuguese, with abstract in English).

Dinardo-Miranda, L.L. 2003. Spittlebugs in sugarcane. Instituto Agronômico, Campinas, SP, Brazil.

Dinardo-Miranda. L.L.; Pivetta, J.P.; Fracasso, J.V. 2008. Economic injury level for sugarcane caused by spittlebug Mahanarva fimbriolata (Stål) (Hemiptera: Cercopidae). Scientia Agricola 65: 16-24.

Folin, O.; Ciocalteu, V. 1927. On tyrosine and tryptophane determinations in proteins. The Journal of Biological Chemistry, 73: 627-50.

Gonçalves, T.D.; Mutton, M.A.; Perecin, D.; Campanhão, J.M., Mutton, M.J.R. 2003. Raw materials quality for different levels of spittlebug damage. STAB: Açúcar, Álcool e Subprodutos 22: 29-33. (in Portuguese).

Lane, J.H.; Eynon, L. 1934. Detemination of Reducing Sugars by Fehling solution with methylene blue indicator. Norman Rodger, London, UK.

Mendonça, A.F.; Barbosa, G.V.S.; Marques, E.J. 1996. Sugarcane spittlebugs. (Hemiptera: Cercopidae) in Brazil 169-192. In: Mendonça, A.F., ed. Pragas da Cana-de-Açúcar: Insetos and Cia, Maceió, AL, Brazil. (in Portuguese).

Novaes, F.V. 1992. Production of Brandy: Quality of Raw Material. p. 93-132. In: Mutton, M.J.R.; Mutton, M.A., eds. Aguardente de cana: produção e qualidade. FUNEP, Jaboticabal, SP, Brazil. (in Portuguese).

Okolo, B.; Johnston, J.R.; Berry, D.R. 1987. Toxicity of ethanol, $\mathrm{n}$-butanol and iso-amyl alcohol in Saccharomyces cerevisiae when supplied separately and in mixtures. Biotechnology Letters 9: 431-434.

Oliva-Neto, P.; Yokoya, F. 1997. Effects of nutritional factors on growth of Lactobacillus fermentum mixed with Saccharomyces cerevisiae in alcoholic fermentation. Revista de Microbiologia 28: 25-31.

Polakovic, M.; Handriková, G.; Kosik. M. 1992. Inhibitory effects of some phenolic compounds on enzymatic hydrolysis of sucrose. Biomass and Bioenergy 3: 369-371.

Presotti, L.E.; Mutton, M.A.; Madaleno, L.L.; Ravaneli, G.C. Mutton, M.J.R. 2007. Spittlebug infestation and phenolic compounds in the juice. STAB Açúcar, Álcool e Subprodutos 26: 6-8. (in Portuguese).

Ravaneli, G.C.; Madaleno, L.L.; Presotti, L.E.; Mutton, M.A.; Mutton, M.J.R. 2006. Spittlebug infestation in sugarcane affects ethanolic fermentation. Scientia Agricola 63: 543-546.

Schneider, F. 1979 Sugar Analysis ICUMSA Methods. ICUMSA, Peterborough, UK.

Simioni, K.R.; Silva, L.F.; Barbosa, V.; Ré, F.E.; Bernadino, C.P.; Lopes, M.L.; Amorim, H.V. 2006. Effect of variety and harvest time in total phenols in sugarcane. STAB Açúcar, Álcool e Subprodutos 24: 36-39. (in Portuguese).

Souza, Z.M.; Paixão, A.C.S.; Prado, R.M.; Cesarini, L.G.; Souza, S.R.; 2005. Handling trash cane harvested without burning, productivity and quality of sugarcane juice. Ciência Rural 35: 1062-1068. (in Portuguese with English abstract).

Stupiello, J.P. 1999. Talking with sugarcane. STAB Açúcar, Álcool e Subprodutos 17: 13. (in Portuguese).

Taiz, L.; Zeiger, E. 2004. Plant Physiology . 3ed. Artmed, Porto Alegre, RS, Brazil. (in Portuguese).

Tanimoto, T. 1964. The press method of cane analysis. Hawaiian Planter's Record 57: 133-150.

Received May 22, 2009

Accepted April 12, 2010 